\title{
医療画像から生成されるボクセルデータ上での血流および血管壁の連成解析
}

\section{Simulation of Interaction between Blood Flow and Blood Wall on Voxel Data that derived from Medical Images}

\author{
○ 熊畑 清 \\ 正 渡邉 正宏 \\ Kiyoshi KUMAHATA \\ Kazuhiro NOGUCHI \\ Masahiro WATANABE \\ Teruo MATSUZAWA
}
（北陸先端大院）
（北陸先端大）

\author{
学 野口 和博 \\ 正 松澤 照男
}

（北陸先端大院）

(北陸先端大)
Japan Advanced Institute of Science and Technology (JAIST)

School of Information Science, Asahidai 1-1, Nomi, Ishikawa

JAIST, School of Information Science

JAIST Center for Information Science

JAIST Center for Information Science

Key Words: Volume Data, Voxel Data, Blood Flow, Blood Vessel, Interaction Analysis, Medical Images

\section{1. 緒言}

血流と血管壁の力学的な相互作用が血管病に関与してい ることが, 血管の疾病が血流が乱れる所でよく発生すること からわかる[1][2]. この相互作用は興味哚い現象であり計算 力学的アプローチによる研究もなされてきている[3].

人体形状は非常に複雑かつ個人個人の差異があるため, 従 来計算機シミュレーションが扱ってきた工業的な問題のよ うに格子生成のためCADデータを用いることは困難であり， また人体内で起こる複雑な現象を扱うには流体・構造の連成 解析となることが多く，一般に非構造格子が用いられること が多いが，その作成と利用には非常に高度なノウハウと多大 なリソースを必要とする[4][5].

計算機シミュレーションを医療の診断・治療のツールとし て使いたいという需要が高まってきているが，上述の格子生 成の困難により医師・医療技術者がツールとして計算機シ ミュレーションをツールとして使うことは困難である.

ツールとして使うことを考えると，医療にとって本質的で はない作業は鿵蔽したい, そこで我々は血流と血管壁との連 成解析を, 人体形状の $\mathrm{CAD}$ データから作成する非構造格子 ではなく，広く普及している画像診断機器からの高精度医療 画像を用いて作成したボクセルデータを利用して行うシ ミュレーションシステムの開発を行った.

\section{2. 連成解析}

連成解析には, 複数の解析場の独立した解析を, 互いに結 果を参照しあう反復を行う弱連成と, 解析場の離散化を同時 に行って解く強連成がある. 強連成は精度が高いが改良が困 難である。弱連成は各解析を別個に行えるため改良が容易で 将来性に富む。そのため本システムを弱連成に基づいて設計 した.

\section{3. システムの概要と流れ}

本システムは弱連成であるため, 医療画像からのボクセル 生成, 流体解析, 荷重定義, 弾性壁の作成, 構造解析, ボリュー ムモーフィングの順に各ステージを実行する.

まずボクセル生成ステージではCTからの断面画像を重ね て3Dボリュームデータを作成し, 各セルを血液に相当するか 否かで流体セルと非流体セルとに分けボクセルを作成する.

次いで流体解析ステージでは非圧縮粘性流れの Navier-Stokes方程式と連続の式を差分法で解く. その際の境 界条件は各セルの側面ごとに指定する。

求められた圧力から荷重定義ステージで流体・非流体境界
部に構造解析のための荷重を定義する.

弾性壁作成ステージではボクセル中の流体セル周囲のセ ルを弾性体セルとして定義し, 構造解析ステージにおいて弾 性壁の忍力・変位を計算する.

求められた変位からボクセル中の輝度值の分布を輝度の 移流方程式を解く事により求め, 形状の変形を表現する。こ の新たなボリュームデータから再びボクセル生成を行い弱 連成の反復を続ける.

血流と血管壁との相互作用による流れの様相と血管壁の 変形を模した計算例を以下に示す.

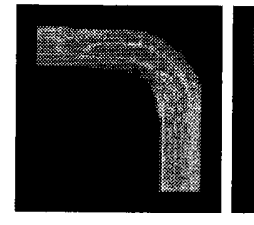

time

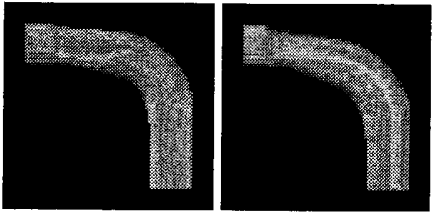

Fig1 Morphed Wall and Streamline

5. 結言

医療画像からダイレクトに作成したボクセルデータを用 いての血流・血管壁連成解析システムを作成した.

我々は本システムを弱連成に基づいて設計し，その際各ス テージをファイルによりデータを交換する独立したプログ ラムとして作成したため, 各ステージの改良・交換を行うこ とが容易であり, 各ステージをネットワーク上の別の計算機 上で分散的に実行するような搪張も容易である。

\section{参考文献}

[1] Glagov S, Zarins C, Giddens DP, Ku DN, "Hemodynamics and atherosclerosis. Insights and perspectives gained from studies of human arteries", Arch Pathol Lab Med, 112(1988), pp.1018-1031.

[2] Schievink WI, "Intracranial Aneurysms", N engl J Med, 336 (1997), pp. $28-40$.

[3] D.Mori, T.Yamaguchi, "Computational Fluid Dynamics Ana- lysis of the Blood Flow in the Thoracic Aorta on the Development of Aneurysm", J Jpn Coll Angiol, 43(2003), pp.94-97.

[4] 渡邊, 松澤, "医療画像から再構築した大動脈瘤内の定常流れの 検討", 日本シミュレーション学会誌 Vol.23(2004) No.1, pp.14-21.

[5] M.Watanabe, T.Matsuzawa, "Computational Simulation of Flow in a Dissecting Aortic Aneurysm Reconstructed from CT Images", Proceedings of ISCT:5th International Symposium on Computational Technologies for Fluid / Thermal / Chemical Systems with Industrial Applications, ASME (2004). 